
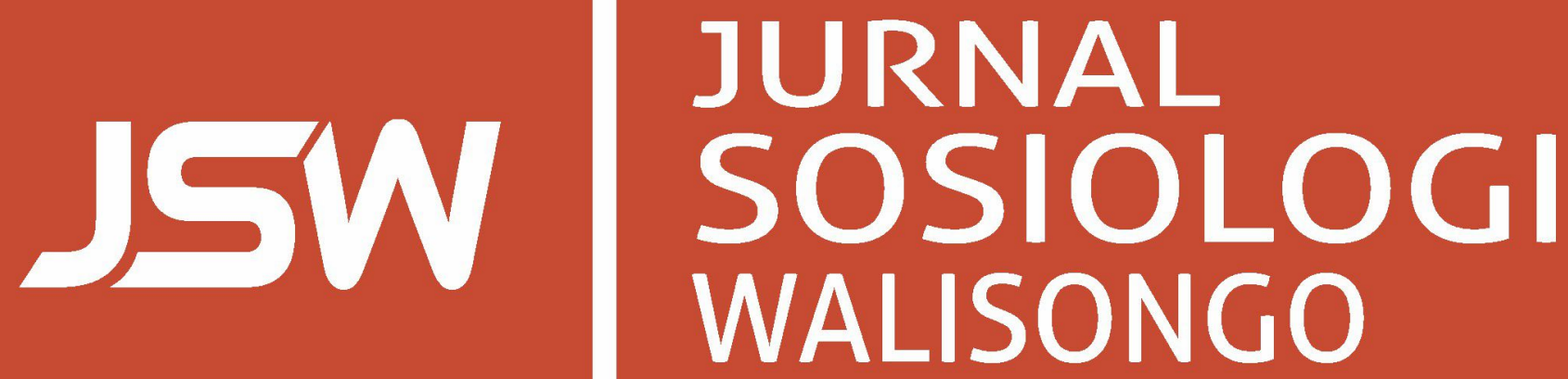

Studi Etnoekologi tentang Nelayan dan Jaring Cantrang

di Kabupaten Rembang

Hesti Rofika Sari, Nugroho Trisnu Brata

Perlawanan Visual Perempuan dalam Poster

Misbah Zulfa Elizabeth

Kearifan Budaya Lokal sebagai Benteng Munculnya Konflik Agama Muhammad Alfan Sidik

Ulama Pasca Sunan Gunung Jati: Jaringan Intelektual Islam Cirebon Abad ke-16 sampai dengan Abad ke-18

Didin Nurul Rosidin

Membangun Harmoni Sosial: Kajian Sosiologi Agama tentang Kearifan Lokal sebagai Modal Dasar Harmoni Sosial David Samiyono

Analisis Komparatif atas Hasil Tracer Study Program Studi Hubungan Internasional dan Administrasi Negara Muhyar Fanani, Akhriyadi Sofian, Kaisar Atmaja, Endang Supriadi

Melihat Indonesia dari Jendela Papua: Kebinekaan dalam Rajutan Budaya Melanesia Akhmad Kadir 

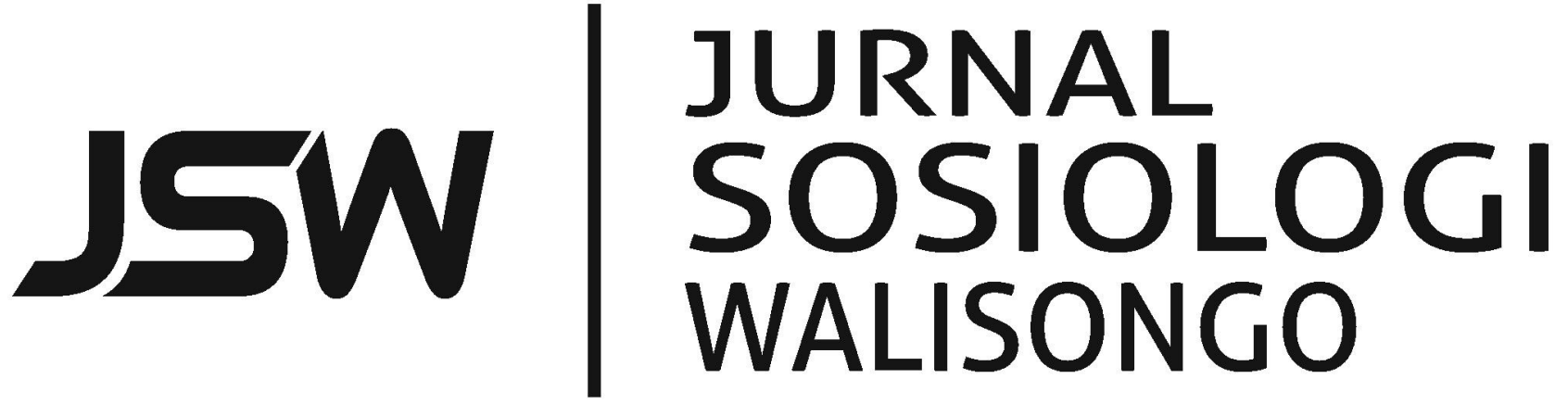

JSW: Jurnal Sosiologi Walisongo - ISSN 2503-3166 (print) ISSN 2503-3182 (online) is a critical, reflective, and transformative academic media that is published by Laboratorium Sosiologi, Fakultas IImu Sosial dan IImu Politik, Universitas Islam Negeri Walisongo Semarang, in the effort for developing the discipline of Sociology having the perspective of unity of sciences. Article is based on research in all division of sociology like sociology of religion, sociology of politic, sociology of law, sociology of development, urban/rural sociology, democracy, social ethic, anthropology, community development, social philosophy, gender, and social welfare.

\section{Editor in Chief}

Misbah Zulfa Elizabeth, Universitas Islam Negeri Walisongo, Semarang

\section{Expert Editor}

Abu Rokhmad, Universitas Islam Negeri Walisongo, Semarang

Muhyar Fanani, Universitas Islam Negeri Walisongo, Semarang

Thohir Yuli Kusmanto, Universitas Islam Negeri Walisongo, Semarang

\section{Editor}

Kaisar Atmaja, Universitas Islam Negeri Walisongo, Semarang

Akhriyadi Sofian, Universitas Islam Negeri Walisongo, Semarang

Nur Hasyim, Universitas Islam Negeri Walisongo, Semarang

\section{Layout Editor}

Helmi Suyanto, Universitas Islam Negeri Walisongo, Semarang

Ulul Azmi, Universitas Islam Negeri Walisongo, Semarang

\section{Publisher}

LABORATORIUM SOSIOLOGI

Fakultas IImu Sosial dan IImu Politik

Universitas Islam Negeri Walisongo

Semarang - Indonesia

\section{Address}

Gedung A - Fakultas IImu Sosial dan IImu Politik (FISIP)

Universitas Islam Negeri Walisongo, Semarang - Indonesia

Jl. Prof. Dr. HAMKA, Km. 2 Tambakaji Ngaliyan Semarang 50185

Phone +62.24 - 76435986

e-mail:jurnal.sosiologi@walisongo.ac.id 


\section{Table of Contents}

Studi Etnoekologi tentang Nelayan dan Jaring Cantrang di Kabupaten Rembang

Hesti Rofika Sari, Nugroho Trisnu Brata (Universitas Negeri

Semarang)

$135-146$

Perlawanan Visual Perempuan dalam Poster

Misbah Zulfa Elizabeth (Universitas Islam Negeri Walisongo,

Semarang)

$147-160$

Kearifan Budaya Lokal sebagai Benteng Munculnya

Konflik Agama

Muhammad Alfan Sidik (STAI Natuna)

$161-176$

Ulama Pasca Sunan Gunung Jati: Jaringan Intelektual Islam

Cirebon Abad ke-16 sampai dengan Abad ke-18

Didin Nurul Rosidin (Institut Agama Islam Negeri Syekh Nurjati,

Cirebon)

$177-194$

Membangun Harmoni Sosial: Kajian Sosiologi Agama tentang

Kearifan Lokal sebagai Modal Dasar Harmoni Sosial

David Samiyono (UKSW, Salatiga)

$195-206$

Analisis Komparatif atas Hasil Tracer Study Program Studi

Hubungan Internasional dan Administrasi Negara

Muhyar Fanani, Akhriyadi Sofian, Kaisar Atmaja, Endang Supriadi

(Universitas Islam Negeri Walisongo, Semarang)

$207-224$

Melihat Indonesia dari Jendela Papua: Kebinekaan dalam

Rajutan Budaya Melanesia

Akhmad Kadir (Universitas Cendrawasih, Jayapura)

$225-246$

Author Guidelines

JSW: Jurnal Sosiologi Walisongo - Vol 1, No 2 (2017) 



\title{
Membangun Harmoni Sosial: Kajian Sosiologi Agama tentang Kearifan Lokal sebagai Modal Dasar Harmoni Sosial
}

\author{
David Samiyono \\ Universitas Kristen Satya Wacana, Salatiga \\ (e-mail: d_samiyono@yahoo.com)
}

\begin{abstract}
Every ethnic in Indonesia have an unique local wisdom. This local wisdom is usually used to resolve any problems or conflicts. And most conflict that have happened in Indonesia is SARA. SARA is an acronym for suku (ethnict), agama (religion), ras (race), dan antar golongan (amongst group community). From social economic problem, cultural, religion, or even political problem such as election of head village and presidential election in Indonesia is related to SARA conflict. Local wisdom is every values, norms, rules, that live in society. This local wisdom binds people and become the way of life in society. This paper would try to contribute how local wisdom have significant role to build social harmony in society. And all datas that have been collected for this paper are the collection of research from all over Indonesia to build harmony based on local wisdom.
\end{abstract}

Setiap etnik di Indonesia mempunyai keunikan kearifan lokal. Kearifan lokal tersebut biasanya dimanfaatkan untuk memecahkan berbagai permasalahan atau konflik. Dan konflik paling banyak yang terjadi di Indonesia adalah konflik SARA. SARA merupakan akronim dari suku, agama, ras, dan antar golongan. Dari permasalahan sosial ekonomi, kultural, agama, atau bahkan permasalahan politik seperti pemilihan kepala desa dan pemilihan presiden di Indonesia yang terkait dengan konflik SARA. Kearifan lokal merupakan setiap nilai, norma, aturan, yang tinggal di masyarakat. Kearifan lokal tersebut mengikat masyarakat dan menjadi pedoman hidup di masyarakat. Tulisan ini akan mencoba untuk memberikan kontribusi bagaimana kebijakan lokal mempunyai peran yang signifikan untuk membangun harmoni sosial di masyarakat. Dan semua data yang sudah dikumpulkan untuk tulisan ini merupakan kumpulan riset dari seluruh Indonesia untuk membangun harmoni sosial yang berdasar pada kearifan lokal.

Keywords: local wisdom; conflict; social harmony 


\section{Pendahuluan}

Indonesia dengan masyarakatnya yang dikenal sebagai masyarakat yang ramah tamah, ternyata belum sepenuhnya benar bila melihat masih sering terjadinya konflik antar etnis atau agama di beberapa daerah. Hal ini menunjukkan bahwa budaya damai belum sepenuhnya menjadi karakter masyarakat Indonesia. Soekanto (1982) menyatakan dalam karyanya bahwa ketika ada interaksi antara dua kelompok masyarakat (etnis) yang berbeda, maka ada beberapa kemungkinan, diantaranya adalah terjadinya kerjasama berdasarkan mutualis simbiosis, terjadinya konflik yang diakibatkan faktor ekonomi atau kecemburuan sosial, dan atau terjadi akomodasi. Dari beberapa peristiwa tersebut faktor konfliklah yang selanjutnya dapat menimbulkan perpecahan diantara masyarakat jika tidak dikelola dengan baik. Konflik bernuansa sara dan politik yang terjadi di beberapa daerah merupakan bukti konkret belum tersentuhnya akar rumput oleh diskursus keanekaragaman budaya dan agama, serta memperlihatkan bahwa wacana ini baru bergulir di kalangan para elite. Akar dari konflik itu adalah masalah-masalah ekonomi dan politik. Pada tahap lanjutan, keanekaragaman budaya dan agama telah dieksploitasi untuk menjustifikasi dan memperluas medan konflik. Pada satu sisi konflik dapat memecah belah atau me- rugikan, akan tetapi apabila konflik dapat dikelola dengan baik maka hasilnya akan positif. Misalnya, semakin mempererat hubungan antar satu individu dengan individu yang lain, atau munculnya aturan baru yang dapat mengakomodasi kepentingan besama.

Kajian ini menggunakan pendekatan sosiologi agama untuk melihat fenomena konflik yang sering terjadi di masyarakat kita. Alasan menggunakan pendekatan ini adalah, pertama pada umumnya permasalahan yang sering terjadi di masyarakat Indonesia tidak bisa dilepaskan dari kedua hal tersebut. Sebuah contoh, kasus yang banyak mendapat perhatian dari masyarakat Indonesia yang cukup fenomenal adalah mengenai penodaan agama yang dituduhkan kepada Basuki Cahaya Purnama, Gubernur DKI Jakarta. Mengapa masyarakat di luar Jakarta sampai di seluruh pelosok tanah air merespon, oleh karena hal tersebut berkaitan dengan agama. Agama di sini digunakan sebagai alat legitimasi untuk mencapai kepentingan oleh sekelompok masyarakat, pada saat bertepatan dengan pemilihan gubernur baru DKI Jakarta. Pada sisi yang lain, seperti faktor ekonomi, korupsi atau peningkatan kesejahteraan masyarakat tidak mendapatkan apresiasi. Disinilah letak sensitivitas agama dalam masyarakat kita. Kasus lain yang tidak sampai di ranah keagamaan adalah terjadinya konflik etnis di Kalimantan Tengah dan Kalimantan 
Barat. Pertentangan antara etnis Madura dengan etnis Dayak, atau etinis Madura dengan etnis Melayu. Secara khusus konflik suku Dayak dengan Madura menimbulkan kerugian baik materi maupun jiwa yang begitu banyak. Masyarakat terpecah menjadi dua. Pertanyaan yang perlu dijawab adalah dimana peran tokoh agama dan tokoh masyarakat dalam konflik tersebut? Apakah justru memperkeruh atau melerai? Masih banyak lagi konflik-konflik yang terjadi di tanah air yang perlu mendapat perhatian. Jika kondisi tersebut terjadi begitu lama maka akan mengancam disintegrasi bangsa ini. Semua orang merindukan masyarakat yang aman, damai, tentram dan harmonis. Oleh karena masyarakat sangat dinamis maka impian tersebut terkadang hanya sebuah cita-cita saja. Lalu apa yang sesungguhnya diperlukan oleh bangsa ini? Ada beberapa pemikiran dalam kajian ini, diharapkan akan menjadi sumbangan kecil dalam membangun harmoni sosial bangsa ini.

Metode pendekatan yang digunakan dalam kajian ini adalah kualitatif. Mengapa kualitatif, karena permasalahan konflik yang begitu komplek diperlukan data-data yang sangat mendalam hasil dari wawancara atau studi dokumentasi. Jika ada datadata kuantitatif, maka data tersebut akan digunakan sebagai data pendukung argumentasi atau temuan lapangan. Data yang diperoleh dalam karya ilmiah ini merupakan hasil withdrawal dari bank data yang sudah dimiliki oleh peneliti dari pengalaman penelitian di beberapa tempat, diantaranya: di Paranggean (Kalteng); Kab. Landak dan Jagoi Babang daerah perbatasan Indonesia-Malaysia; Ambon; Tentena; Atambua khususnya di Kabupaten Belu; Bali dan Medan. Semua penelitian dilakukan dalam rangka studi harmoni sosial berdasarkan kearifan lokal. Dipercaya bahwa Indonesia memiliki berbagai macam suku - etnis. Setiap suku pasti memiliki kearifan lokal yang digunakan sebagai way of life masyarakat tersebut, ketika ditemukan sebuah kearifan lokal dalam masyarakat, maka budaya atau tradisi tersebut dapat digunakan sebagai dasar damai atau hidup harmoni dengan orang lain yang berbeda suku dan atau agama. Misalnya, tradisi ngejot. Ini adalah budaya saling memberi makanan kepada tetanggga yang berbeda agama atau suku. Tradisi tersebut dilakukan setiap memperingati hari raya keagamaan. Di Desa Kepaon, Denpasar ada desa yang penduduknya mayoritas Hindu, Islam dan Kristen. Mereka melaksanakan ngejot dalam rangka menjaga harmoni sosial. Hal yang sama dilakukan oleh masyarakat Dayak di Jagoi Babang. Sebagaimana di Jawa orang saling berkunjung di hari raya Idul Fitri, maka di Jagoi Babang ketika ada upacara gawai, masyarakat saling berkunjung bahwa warga Malaysia yang masih satu suku juga berkunjung ke keluarga di perbatasan. Tak 
kalah menariknya di Jawa banyak kearifan lokal yang dimiliki oleh orang Jawa. Misalnya, seorang perempuan tidak boleh makan di depan pintu rumah utama. Kepercayaan yang ada, nanti sulit mencari jodoh. Kemudian apabila terjadi konflik atau salah paham sebaiknya bersikap diam, daripada bertengkar, nanti malu jika dilihat oleh tetangga. Hal tersebut sesungguhnya tidak akan menyelesaikan permasalahan. Jadi berdiam diri meupakan karakter orang Jawa jika terlibat dalam permasalahan. Masih banyak budaya lokal yang dimiliki oleh masyarakat yang dapat digunakan untuk membangun harmoni bangsa, namun mengapa masih saja terjadi konflik di beberapa daerah, apa sesungguhnya yang diperlukan oleh masyarakat kita ini? Berikut adalah beberapa pokok pikiran yang perlu ditambah dan atau dikembangkan agar semakin sempurna.

\section{Kearifan Lokal}

Secara etimologis, kearifan (wisdom) berarti kemampuan seseorang dalam menggunakan akal pikirannya untuk menyikapi sesuatu kejadian, obyek atau situasi. Pada sisi yang lain kearifan lokal dapat diartikan sebagai gagasan, nilai atau pandangan masyarakat terhadap sebuah fenomena dan menyikapinya dengan bijaksana. Kearifan lokal dipercayai oleh masyarakat di suatu tempat tersebut dan sudah diikuti secara turun temurun dan sifatnya mengikat. Apabila ada orang yang melanggar maka akan ada sanki atau akibatnya.

Dengan demikian, kearifan lokal secara substansial merupakan nilai dan norma yang berlaku dalam suatu masyarakat yang diyakini kebenarannya dan menjadi acuan dalam bertindak dan berperilaku sehari-hari. Oleh karena itu, kearifan lokal merupakan entitas yang sangat menentukan harkat dan martabat manusia dalam komunitasnya (Geertz 2007). Kearifan Lokal memiliki beberapa ciri diantaranya, pertama memiliki kamampuan untuk mengendalikan. Misalnya, kearifan lokal yang dimiliki oleh masyarakat Ambon dikenal dengan sebutan Pela gandong. Untuk menekan tindak kriminalitas ataupun tindakan yang lain maka, setiap pelanggar hukum atau norma masyarakat akan dikenakan sanksi adat. Nampaknya sanksi adat tersebut lebih efektif sehingga tidak perlu smpai ke ranah hukum positif. Kedua, kearifan lokal mampu dijadikan sebagai benteng untuk survival dari pengaruh budaya luar. Oleh karena hal ini berkaitan dengan identitas lokal atau local identity masyarakat tertentu. Hal inilah yang membedakan budaya satu dari yang lain. Ketiga, kearifan lokal mampu memberi arah perkembangan budaya agar tidak terpengaruh budaya luar yang tidak sesuai dengan norma atau kaidah masyarakat setempat. Contoh lain kearifan lokal yang dimiliki oleh masyarakat Bali dan 
Lombok disebut awig-awig. Awig-awig adalah aturan adat yang menjadi pedoman untuk bertindak dan bersikap terutama dalam hal berinteraksi dan mengolah sumber daya alam dan lingkungan di daerah Lombok Barat dan Bali.

Banyaknya kearifan lokal yang dimiliki oleh bangsa Indonesia menunjukkan kekayaan yang dimiliki oleh masyarakat. Apabila hal tersebut dipelihara sebagai sebuah kemajemukan bangsa kita, maka ini merupakan harta yang tidak ternilai dan dapat digunakan sebagai alat atau modal dasar sebuah harmoni bangsa. Kekayaan tersebut sebaiknya diajarkan kepada masyarakat dan menjadi bagian modal pendidikan multikultural.

\section{Pendidikan Multikultural}

Strategi pendidikan multikultural sangat penting dalam menumbuhkan karakter perdamaian bagi masyarakat, karena masyarakat akan mengalami sendiri interaksi di dalam lingkungan mereka masingmasing. Untuk mewujudkan hal tersebut, maka dapat diawali dengan pendidikan multikultural melalui pendidikan formal di sekolah-sekolah. Hal ini sangat penting mengingat kita hidup dengan orang lain yang (bisa saja) berbeda keyakinan, status sosial dan etnis. Jika sejak dini peserta didik diajarkan bagaimana mengenal orang lain yang 'berbeda' tadi maka jiwa inklusif akan dimiliki, dan jiwa tersebut yang diperlukan untuk membangun harmoni sosial bangsa ini. Konflik terjadi dapat diakibatkan oleh karena minimnya pemahaman terhadap 'the others'.

Dalam pendidikan multikultural, sebaiknya semua aspek kelembagaan harus menerapkan sistem dan metode yang dapat menanamkan sifat multiculturalisme dan pluralisme. Melalui sifat yang dimiliki oleh para peserta didik maka selanjutnya mereka akan mampu menggali dan mengembangkan nilai-nilai perdamaian dan toleransi. Oleh karena itu guru selain harus menguasai dan mampu secara profesional mengajarkan mata pelajaran, tetapi juga harus mampu memberikan penanaman nilai-nilai pendidikan multikultural yaitu demokrasi, humanisme, pluralisme, dan memiliki religiusitas yang dapat dipertanggungjawabkan untuk kemanfaatan masyarakat yang plural. Oleh karena itu pelaksanaan pendidikan budaya damai menjadi sangat diperlukan terutama di daerah-daerah yang rawan konflik.

Melalui penelitian berjudul Pendidikan Multikultural di Pulau Dewata, Wibowo menyebutkan bahwa pendidikan agama berbasis multikultural merupakan keniscayaan yang harus diterapkan dalam lembaga pendidikan di Indonesia (Wibowo 2015). Pendidikan agama berbasis multikultural akan melahirkan generasi-generasi yang siap bergaul, berinteraksi, bekerjasama, saling isi mengisi, saling harga menghargai, hormat menghormati sesama 
manusia tanpa harus saling menyakiti atau menganggap salah ajaran agama dan budaya yang berbeda.

Pluralisme agama menolong kita untuk rendah hati menyadari bahwa sikap superioritas tidak bermanfaat untuk mengerti orang lain lebih baik sebab Allah mengasihi semua manusia tanpa terkecuali, dan karenanya kita harus menjadi sesama atau menjadi sahabat bagi saudarasaudara kita yang berkepercayaan lain (Darmaputera 1995: 194). Pluralisme agama bukan berarti percampuran atau sinkretisme, sebab keunikan masingmasing agama tetap dapat dipertahankan dan dapat dikomunikasikan; dan bukan untuk dipertandingkan. Keterbukaan semacam ini menumbuhkan perdamaian dan toleransi dan bukan pada tempatnya lagi saling menghujat, menyalahkan, apalagi membunuh (Abdullah 1999: 58-59).

Model pluralisme Kniter dengan dialog pluralistik yang bertanggungjawab global dapat dipertimbangkan untuk mengatasi masalah kemiskinan dan kerusakan ekologi dalam konteks kita. Agama-agama harus memberikan kontribusi yang berarti mengatasi kedua masalah besar itu. Model ini mendorong warga masyarakat untuk berdialog sebab dialog agama bukanlah monopoli kaum elit agama. Hakikat pendidikan Paulo Freire (dalam Murtiningsih 2004) diarahkan atas pandangannya terhadap manusia dan dunia, pendidikan harus berorientasi pada pengenalan realitas diri manusia dan dirinya sendiri, serta memiliki kesadaran dan berpotensi sebagai Man of Action untuk mengubah dunianya. Pendidikan adalah instrumen untuk membebaskan manusia supaya mampu mewujudkan potensinya.

"Tujuan utama manusia adalah humanisasi yang ditempuh melalui pembebasan. Proses untuk menjadi manusia secara penuh hanya mungkin apabila manusia berintegrasi dengan dunia. Dalam kedudukannya sebagai subjek, manusia senantiasa menghadapi berbagai ancaman dan tekanan, namun ia tetap mampu terus menapaki dan menciptakan sejarah berkat refleksi kritisnya." (Freire, dalam Murtiningsih 2004: 55). Pendidikan dengan pendekatan kemanusiaan sering diidentikkan dengan pembebasan, yakni pembebasan dari hal-hal yang tidak manusiawi. Jadi, untuk mewujudkan pendidikan yang memanusiakan manusia dibutuhkan suatu pendidikan yang membebaskan dari unsur dehumanisasi

Dalam era globalisasi, agama tetap memainkan peranan penting dalam integrasi bangsa dan agar supaya masyarakat tidak hanyut dalam arus fundamentalisme dan liberalisme, karena keduanya tidak peduli dengan eksistensi orang lain. Jika agamaagama tidak dapat berdialog, maka kekerasan atas nama agama dapat mencederai kesatuan bangsa dan menciptakan ketakutan dalam masyarakat. Pluralisme agama menjadikan dikotomi mayoritas- 
minoritas tidak relevan lagi sebab semua umat beragama berpotensi sama baiknya membangun kehidupan bersama secara damai dalam bingkai keberagaman dalam kesatuan bangsa (Bhinneka Tunggal Ika).

Untuk itu, agar dapat hidup dalam keanekaragaman agama secara harmoni, seharusnyalah agama itu sendiri harus juga menyadari dan menyadarkan warganya bahwa pluralitas agama bukanlah dosa dan sesuatu yang harus dinisbihkan, melainkan suatu potensi yang besar dalam mengembangkan kehidupan beragama yang satu dengan yang lain dalam penyembahan kepada Tuhan yang absolut. Tidak ada satu agama yang absolut. Walaupun agama itu memang merupakan pernyataan yang Absolut, tetapi itu tidak menjadikan agama sebagai absolut, melainkan hanya Tuhan yang absolut, benar dan final bagi manusia dan masyarakat (Knitter 1985: 134). Ini berarti kepercayaan akan kemahakuasaan Tuhan atas segala sesuatu termasuk manusia dan semua aspek kehidupannya mengimplikasikan bahwa kekuasaan, kehendak dan kebenaran Tuhan tidak dapat dibatasi oleh siapa pun dan tidak dapat dibatasi oleh apa pun, termasuk agama yang diyakini dan dianut (Sutarno 2004: 282).

Dalam era globalisasi, agama tetap memainkan peranan penting dalam integrasi bangsa dan agar masyarakat tidak hanyut dalam arus individualisme, fundamentalisme dan liberalisme, karena ketiganya tidak peduli dengan eksistensi orang lain. Jika agama-agama tidak dapat berdialog, maka kekerasan atas nama agama dapat menciderai intergerasi dan menciptakan ketakutan dalam masyarakat. Pluralitas agama menjadikan dikotomi mayoritas-minoritas tidak relevan lagi, sebab semua umat beragama berpotensi sama baiknya membangun kehidupan bersama secara damai dalam bingkai keberagaman. Sebagai realitas faktual pluralitas agama haruslah direspon secara mengena dan relevan serta dapat dimanfaatkan sebagai aset bersama untuk melaksanakan panggilan bersama dalam mengupayakan kesejahteraan dari semua untuk semua. Ia mengandung semangat ganda bahwa satu sisi tak hendak mengingkari adanya perbedaan, bukan hanya sebagai kenyataan yang harus diterima, tetapi juga sebagai modal yang harus terus dipelihara, bahkan dikembangkan, dan di sisi lain, perbedaan tidak boleh menghalangi dan mengalahkan semangat untuk bekerja sama, membangun kebersamaan, serta tekad, semangat, dan upaya untuk mewujudkan cita-cita bersama dalam mengembangkan kehidupan manusia yang ideal: religius, berkeadilan, damai, dan sejahtera. Dengan demikian bahwa pluralitas agama suatu fakta penting yang dapat menjadi titik pijak bersama pada peran fungsional agama dalam menjalankan perannya yang integratif dan menciptakan 
harmoni sosial dalam masyarakat (Geertz 1960: 475).

Menurut hasil dialog pengembangan wawasan multikultural antara pemuka agama pusat dan pemuka agama di Provinsi Bali, dinyatakan adanya potensi kerukunan yang dibangun dari kearifan lokal masyarakat Bali. Misalnya budaya Menyama Braya, slogan Tat Twam Asi dan Tri Hita Karana, menjadi pondasi penting bagi masyarakat Bali untuk mewujudkan harmoni sosial bangsa (Mudzhar 2003: 282-283). Begitu juga masyarakat di Poso memiliki kearifan lokal yang disebut sintu maroso yang dapat digunakan sebagai dasar resolusi konflik internal.

Isu-isu kerukunan tentu saja tidak lepas dari adanya persoalan-persoalan yang muncul dan berkembang di masyarakat. Misalnya, pemahaman masyarakat tentang wawasan multikulturalisme masih harus disosialisasikan bukan hanya kepada peserta didik di sekolah saja, melainkan juga dimungkinkan di masyarakat, mengingat bangsa Indonesia memiliki kemajemukan yang tinggi dibandingkan dengan negara lainnya.

\section{Pendidikan Budaya Damai}

David W. Johnson dan Roger T. Johnson dalam artikelnya yang berjudul Essential Components of Peace Education menyebutkan lima elemen penting untuk membangun dasar pendidikan perdamaian. Satu diantaranya adalah "students must be taught how to engage in integrative negotiations and peer mediation to resolve their conflicts with each other constructively". Dari uraian Johnson sangat jelas bahwa keikutsertaan peserta didik dalam studi perdamaian terutama dalam penyelesaian permasalahan yang ada di sekitar kita, dengan demikian peserta didik memiliki pengalaman dalam bermasyarakat.

Di dalam teori resolusi konflik dalam studi perdamaian ada tiga hal yang dapat menopang terciptanya perdamaian, yaitu peacemaking, peacebuilding dan peacekeeping. United Nations menggunakan ketiga hal tersebut disebut sebagai alat pemersatu atau alat "perdamaian" pada sebuah wilayah berkonflik. Peacemaking adalah sebuah upaya diplomatis yang digunakan untuk menyelesaikan permasalahan antara pihak yang berkonflik tanpa tindakan kekerasan yang berujung pada perjanjian damai, dan fase ini biasanya setelah konflik. Peacekeeping adalah sebuah intervensi dari pihak ke-3 untuk membantu wilayah berkonflik yang berada dalam keadaan transisi yang dimaknai sebagai memisahkan kedua pihak yang bermasalah dengan menyediakan keamanan serta inisiatif nonmiliter. Peacebuilding adalah skema kerja untuk menghindar akan konflik datang kembali. Sangat berguna untuk mengatur konflik atau memancing konflik yang dapat diselesaikan secara damai. Dalam pemikiran Johan Galtung, tantangan untuk budaya damai 
adalah bagaimana meningkatkan negative peace menjadi positive peace yang intinya menciptakan keadilan sosial, kesejahteraan ekonomi, keterwakilan politik yang efektif.

Pertanyaan yang harus dijawab adalah siapakah yang harus menjadi peserta didik Pendidikan Budaya Damai? Pertama adalah masyarakat, karena merekalah yang saling bersinggungan antara satu dengan yang lain. Ketika masyarakat dapat berpartisipasi dalam membangun budaya damai, maka konflik dapat diminimalisir. Kedua, adalah peserta didik yang sedang dalam proses pendidikan di tingkat dasar sampai perguruan tinggi. Hal ini sangat penting dilakukan karena di bangku pendidikan sangat rentan terhadap manipulasi kebenaran data oleh karena kepentingan pribadi atau golongan.

Prinsip pendidikan sesuai dengan Undang-Undang Nomor 20 Tahun 2003 tentang Sistem Pendidikan Nasional mengamanatkan prinsip-prinsip dalam pelaksanaan pendidikan, yaitu demokratis berkeadilan, dan tidak diskriminatif menghargai kemajemukan. Pendidikan diselenggarakan sebagai satu kesatuan yang sistem terbuka dan multimakna. Pendidikan diselenggarakan dengan memberdayakan semua komponen masyarakat melalui peran serta dalam penyelenggaraan dan pengendalian mutu layanan pendidikan. Sedangkan fungsi pendidikan menurut UU Nomor 20 Tahun 2003 Pasal
3 adalah mengembangkan kemampuan dan membentuk watak serta peradaban bangsa yang bermartabat dalam rangka mencerdaskan kehidupan bangsa, bertujuan berkembangnya kemampuan peserta didik agar menjadi manusia yang beriman dan bertakwa kepada Tuhan Yang Maha Esa, berakhlak mulia, sehat, berilmu, cakap, kreatif, mandiri dan menjadi warga negara yang demokratis serta bertanggung jawab. Menurut UNICEF Pendidikan Perdamaian pada prinsipnya merupakan proses memperkenalkan pengetahuan, keterampilan, sikap dan nilai yang dibutuhkan untuk mewujudkan perubahan perilaku yang akan memungkinkan anak-anak, remaja dan orang dewasa untuk mencegah konflik dan kekerasan, baik terbuka maupun struktural; menyelesaikan konflik secara damai; dan untuk menciptakan kondisi yang kondusif untuk perdamaian, baik secara intrapersonal, Interpersonal, intergroup, nasional atau internasional. (Susan Foundation 1999). Dalam konsepsi UNESCO, damai atau peace diartikan secara luas. 'Peace is more than an absence of war. It means justice and equity for all as the basis for living together in harmony and free from violence, now, but even more so for our children and succeeding generations'. Kata damai mengandung makna lebih dari sekedar tidak terjadi konflik. Damai, bermakna keadilan dan kesetaraan untuk semua, sebagai landasan bersama secara hormonis dan bebas dari tindak kekerasan, 
bukan hanya saat ini saja melainkan juga untuk generasi pada masa yang akan datang. Apabila konsep tersebut dipahami dan dilakukan oleh setiap lapisan masyarakat tanpa harus memberlakukan perbedaan, niscaya kedamaian dan keadilan akan tercipta. Permasalahan yang muncul adalah setiap insan memiliki tujuan dan kepentingan hidup yang berbeda. Ada yang mengutamakan ketentraman hidup, tidur nyenyak urusan materi tidak diutamakan, sebaliknya ada juga yang mengutamakan materi dalam hidup sehingga harus bekerja keras jika memungkinkan dan ada kesempatan norma agama tidak dijadikan sebagai pertimbangan dalam pengambilan keputusan.

\section{Kesimpulan}

Keanekaragaman kearifan lokal yang mencerminkan nilai sosial budaya masyarakat pada umumnya bersifat verbal dan tidak sepenuhnya terdokumentasi dengan baik. Norma-norma sosial yang ada, baik yang bersifat anjuran ataupun yang bersifat larangan, masih perlu pendalaman lebih lajut, terutama ketika hal tersebut memiliki dampak secara nasional. Oleh karena itu perlu dikembangkan suatu bentuk knowledge management terhadap berbagai jenis kearifan lokal tersebut agar dapat digunakan sebagai acuan dalam proses pembangunan manusia seutuhnya yang berjiwa Pancasilais. Modal dasar bagi segenap elit dan segenap agen pembaharu bangsa adalah ketulusan membuang ego pribadi ataupun kelompok, bersedia menggali nilai-nilai budaya masyarakat daerah masing-masing. Masyarakat bersama-sama menggali sumber kehidupan secara arif dan bijaksana, sehingga ada jalan menuju kehidupan yang harmoni, dengan meniadakan konsep hukum rimba, menolong yang lemah, menciptakan kedamaian, keadilan dan kesejahteraan. Keterbukaan merupakan modal dasar dalam setiap aktualisasi pergaulan, pekerjaan dan pembangunan, beserta nilainilai budaya lain yang menyertainya.

Pendidikan perdamaian dan multikultural perlu ditanamkan kepada setiap elemen masyarakat baik dalam keluarga, masyarakat dan pendidikan dasar sampai pendidikan tinggi. Ini menjadi penting supaya ada kesadaran bersama sebagai suatu bangsa yang memiliki keanekaragaman budaya dan agama yang berbeda-beda. Hal itulah yang menjadi fondasi kekuatan bangsa kita. Jangan sampai budaya luar yang lebih konsumeristik akan menghancurkan kearifan lokal yang memiliki.]

\section{Daftar Pustaka}

Abdullah, M. Amin. 1999. "Kebebasan Beragama atau Dialog Antar-agama" (pp. 58-59.), dalam J. B. Banawiratma, dkk., Hak Asasi Manusia Tantangan bagi Agama. Jogyakarta: Kanisius.

Baedowi, Ahmad, dkk. 2015. Potret Pendidikan Kita. Jakarta: Alvabet. 
Cresswell, John W. 1994. Research Design: Qualitative and Quantitative Approaches. London: Sage Publications.

Darmaputera, Eka. 1995. "Teologi Persahabatan antar umat Beragama", dalam Karel Phil Erari ed. Keadilan bagi yang Lemah. Buku Peringatan Hari Jadi ke-67 Prof. Dr. Ihromi, MA. Jakarta.

Denzin, Norman K. and Lincoln, Yvonna S. ed. 1994. Handbook of Qualitative Research. London: Sage Publications.

Freire, Paulo dalam Siti Murtiningsih. 2004., Pendidikan Alat Perlawanan: Teori Pendidikan Radikal Paulo Freire. Yogyakarta: Resist Book.

Haba, John. 2012. "Etnisitas, Hubungan Sosial dan Konflik di Kalimantan." dalam Jurnal Masyarakat dan Budaya 14 (1).

Ishak, Awang Faroek. 2003. Membangun Wilayah Perbatasan Kalimantan dalam rangka Memelihara dan Mempertahankan Integritas Nasional, Jakarta: Indomedia.

Johnson, David W., dan Johnson, Roger T. 2005. "Essential Components of Peace Education". Journal of Peace Education 44 (4): 280-292.

Liliweri. 2005. Prasangka dan Konflik: Komunikasi Lintas Budaya Masyarakat Multikultural. Yogyakarta: LKiS.

Ma'arif, Syamsul. 2007. "Peace Building Melalui Pendidikan Multikultural" dalam Musahadi dkk. Mediasi dan
Resolusi Konflik di Indonesia. Semarang: WMC (Walisongo Mediation Centre) IAIN Walisongo.

Moleong, Lexy, J. 2008. Metode Penelitian Kuantitatif. Bandung: Remaja Rosdakarya.

Newman, W. Lawrence. 1997. Social Research Methods: Qualitative and Quantitative Approaches. London: Allyn and Bacon.

Ritzer, George and Goodman Douglas J. 2004. Teori Sosiologi Modern. Edisi ke 6. Jakarta: Prenada Media.

Ruslikan. 2001. "Konflik Dayak Madura di Kalimantan Tengah: Melacak Akar Masalah dan Tawaran Solusi" Jurnal Masyarakat, Kebudayaan dan Politik, 14 (4): 1-12.

Soekanto, Soerjono. 1982. Sosiologi: Suatu Pengantar. Jakarta: Rajawali.

Susan Foundation. 1999. Peace Education in Unicef. New York: United Nations: Children's Fund Programme Publications 3 UN Plaza.

Turner, H. Jonathan. 1998. The Structure of Sociological Theory. $6^{\text {th }}$ edt. Belmont, CA: Wadsworth Pub. Company.

Wibowo, A.M, 2015. Pendidikan Multikultural di Pulau Dewata, Sebuah Bunga Rampai tentang Pendidikan Multikultural pada SMA di Provinsi Bali. Yogyakarta: Arti Bumi Intaran. 


\section{Author Guidelines}

\section{A. Persyaratan Umum}

1. Naskah merupakan hasil penelitian sosial keagamaan dan modernitas yang sudah diformat sesuai pola penulisan artikel jurnal ilmiah.

2. Naskah diutamakan ditulis dalam Bahasa Inggris.

3. Naskah merupakan karya orisinil (bukan plagiasi) dan belum pernah dimuat di jurnal atau media cetak/online lainnya.

4. Naskah dikirim ke Redaksi JSW: Jurnal Sosiologi Walisongo melalui submission Open Journal Systems (OJS) pada http://journal.walisongo.ac.id/index.php/jsw

5. Naskah diketik menggunakan Microsoft Word format RTF, font Times New Roman, size 12 pt, 1,5 spasi, ukuran halaman A4, dengan panjang tulisan 20-25 halaman (sekitar 5.000 - 7.000 kata).

6. Untuk menperoleh keterangan lebih lanjut, silakan menghubungi redaksi melalui email: jurnal.sosiologi@walisongo.ac.idatau menghubungi kantor redaksi (024) 76435986.

\section{B. Persyaratan Khusus}

1. Naskah merupakan hasil penelitian dalam bidang sosial keagamaan dan modernitas.

2. Naskah tidak mencantumkan nama penulis, instansi, dan alamat email. Nama penulis, instansi, dan alamat email dicantumkan saat melakukan registrasi OJS dan pengisian metadata naskah.

3. Naskah memuat:

a. Judul, dengan ketentuan:

- Judul merupakan rumusan pokok bahasan yang singkat, padat, dan jelas.

- Dalam judul sudah tercantum variabel-variabel utama penelitian.

- Judul diketik dengan hurup kapital tebal (capital, bold).

b. Abstrak, dengan ketentuan:

- Abstrak ditulis dalam bahasa Inggris dan bahasa Indonesia. 
- Abstrak merupakan intisari dari pokok bahasan naskah.

- Abstrak ditulis dalam satu paragraf berjarak satu spasi, dengan panjang 100250 kata.

- Abstrak disajikan secara singkat dan jelas, dengan memuat empa. argumentasi logis, perlunya dilakukan penelitian untuk memecahkan masalah, pendekatan yang digunakan (metode), hasil yang dicapai, serta simpulan yang diperoleh (IMRAD: introduction, methods, results, analysis and discussions).

c. Kata Kunci (keywords) maksimal 5 (lima) kata.

d. Isi naskah, dengan sistematika sebagai berikut:

- Pendahuluan yang meliputi latar belakang masalah, perumusan masalah, tujuan dan manfaat penelitian, serta metodologi yang digunakan (IMRAD: introduction, methods, results, analysis and discussions).

- Review pustaka yang berisi kajian teoretik dan hasil penelitian terdahulu yang relevan.

- Hasil dan pembahasan.

- Simpulan dan rekomendasi.

- Daftar pustaka.

4. Rujukan menggunakan ASA (American Sociological Association).[] 


\section{ACKNOWLEDGEMENTS}

The members of the editorial team of JSW: Jurnal Sosiologi Walisongo extend the gratitude to all the reviewers who have contributed to the peer review process of the manuscripts in Vol 1, No 2 (2017). Professional support and assistance from all respected reviewers have made this journal qualified to be published:

1. Abu Rokhmad, Universitas Islam Negeri Walisongo, Semarang

2. Agus Nurhadi, Universitas Islam Negeri Walisongo, Semarang

3. Misbah Zulfa Elizabeth, Universitas Islam Negeri Walisongo, Semarang

4. Muhyar Fananai, Universitas Islam Negeri Walisongo, Semarang

5. Najahan Musyafak, Universitas Islam Negeri Walisongo, Semarang

6. Thohir Yuli Kusmanto, Universitas Islam Negeri Walisongo, Semarang

7. TriMarhaeni Pudji Astuti, Universitas Negeri Semarang 


\section{\begin{tabular}{l|l} 
JW & $\begin{array}{l}\text { JURNAL } \\
\text { SOSIOLOGI } \\
\text { WALISONGO }\end{array}$
\end{tabular}}

JSW: Jurnal Sosiologi Walisongo - ISSN 2503-3166 (print) ISSN 2503-3182 (online) is a critical, reflective, and transformative academic media that is published by Laboratorium Sosiologi, Fakultas IImu Sosial dan IImu Politik, Universitas Islam Negeri Walisongo Semarang, in the effort for developing the discipline of Sociology having the perspective of unity of sciences. Article is based on research in all division of sociology like sociology of religion, sociology of politic, sociology of law, sociology of development, urban/rural sociology, democracy, social ethic, anthropology, community development, social philosophy, gender, and social welfare. 